\title{
The Absorption and Retention of Magnesium, Zinc, and Copper by Low Birth Weight Infants Fed Pasteurized Human Breast Milk
}

\author{
M. J. DAUNCEY, J. C. L. SHAW, ${ }^{(36)}$ AND J. URMAN \\ Department of Paediatrics, University College Hospital, London, and Medical Research Council Dunn Nutrition \\ Unit, Cambridge, England
}

\begin{abstract}
Summary
Using serial metabolic balance techniques, the absorption and retention of magnesium, copper, and zinc have been measured in six preterm infants (mean gestation 29 weeks), and two term small for gestational age infants $(<1.5 \mathrm{~kg}$ birth weight). The amounts of the minerals retained were compared with the amounts retained by a fetus of equivalent gestational age in utero.
\end{abstract}

The preterm infants absorbed $5.3 \pm 3.5 \mathrm{mg} / \mathrm{kg} \cdot$ day magnesium (43\% of intake, range $1-74 \%$ ) and retained $2.8 \pm 1.3 \mathrm{mg} /$ $\mathrm{kg} \cdot$ day $(25 \%$ of intake, range -15 to $+48 \%)$. The mean postnatal retention over the whole study period, as a percentage of intrauterine accumulation by a fetus of equivalent maturity, was $41 \%$ (range $17-66 \%$ ). The light for dates infants absorbed 5.7 $\mathrm{mg} / \mathrm{kg} \cdot \mathrm{day}$, range $4.0-7.2(81 \%$ of intake, range $51-95 \%)$ and retained $5.4 \mathrm{mg} / \mathrm{kg} \cdot$ day, range $3.3-6.6(76 \%$ of intake, range 41-88\%).

In the preterm infants balance for zinc was negative on average until the 60th day of life. The most negative balance averaged $-0.611 \pm 0.432 \mathrm{mg} / \mathrm{kg} \cdot$ day $(n=6)$ on days $20-22$. All the preterm infants experienced a net loss of body zinc over the period of study (mean $-18.1 \mathrm{mg}$, range -4.2 to $-37 \mathrm{mg}$ ). In contrast the light for dates infants were in positive balance and they absorbed $0.44 \mathrm{mg} / \mathrm{kg} \cdot$ day range -0.06 to $+0.75(56 \%$ of intake, range -35 to $+86 \%$ ) and retained $0.42 \mathrm{mg} / \mathrm{kg} \cdot$ day, range -0.08 to $+0.73(52 \%$ of intake, range -46 to $+82 \%)$.

In the preterm infants balance for copper was negative on average until the 35th day of life, and the most negative balance was $-0.035 \pm 0.061 \mathrm{mg} / \mathrm{kg} \cdot$ day on days $10-12$. Three of the six preterm infants, during the period of study, experienced a net loss of body copper which averaged $0.73 \mathrm{mg}$ (range -1.3 to $-0.3 \mathrm{mg}$ ); the other three retained on average $1.74 \mathrm{mg}$ (range 0.12 to $3.2 \mathrm{mg}$ ). The light for dates infants absorbed and retained $0.045 \mathrm{mg} / \mathrm{kg} \cdot$ day, range 0.004 to 0.079 (57\% of intake, range $12-88 \%$ ).

It is concluded that breast milk supplies enough magnesium but insufficient copper and zinc for preterm infants, with the result that their body stores of copper and zinc cannot develop normally.

\section{Speculation}

Because of the depletion of body stores of copper and zinc a deficiency of these substances is likely to occur in some preterm infants during later infancy.

The amounts of magnesium, zinc, and copper in fetal bodies increase 3-4-fold during the last 3 months of pregnancy. Part of the increase results from the rapid tissue growth characteristic of this period of gestation, but part represents the formation of stores. About half of the copper in the full term fetus is found in the liver as "neonatal hepatic mitochondrocuprein" (13) and about two-thirds of the magnesium and perhaps one-third of the zinc in the body are present in the bones. Because of the extensive remodeling of fetal compact bone after birth (15), much of the magnesium and zinc in bone, as well as the hepatic copper, probably become available to meet the later needs of the growing full term infant.

The infant born 3 months prematurely, however, has much smaller amounts of magnesium, copper, and zinc in his body, and must rely on the fetal intestine to absorb enough of these substances for his needs. Cavell and Widdowson (4) showed that full term infants were in negative balance for copper and zinc in the newborn period, and the reports of Tkacenko (21) and of Widdowson et al. (24) show that this is also true of preterm infants.

The purpose of the present investigation was to measure the absorption and retention of magnesium, zinc, and copper by very low birth weight preterm infants in order to find out in what way their chemical growth, in respect to these elements, differed from that of a fetus of equivalent gestational age. It was hoped to learn to what extent body stores were affected by premature birth, and to find out whether human breast milk could supply the needs of such infants. Light for dates term infants were also studied in order to distinguish the effect of low birth weight from that of immaturity.

\section{PATIENTS AND METHODS}

\section{PATIENTS}

The infants were all admitted to the Intensive Care Unit at University College Hospital because of low birth weight. There were six preterm infants and two term light for dates infants. They all weighed less than $1.5 \mathrm{~kg}$ at birth and none of them was seriously ill during the period of investigation. Details of the infants are given in Table 1.

\section{METABOLIC BALANCE TECHNIQUES}

The reasons for the investigation and the procedures involved were explained to the parents and their agreement obtained. In all but one case metabolic balances were started on the 10th day of life and in the case of the preterm infants each balance period lasted 3 days and was repeated every 10 days until discharge home (Table 1). In the case of the two light for dates infants each balance period lasted 5 days and the balances were performed continuously until discharge. Out of a total of 40 balance periods only one had to be omitted because of diaper rash. The infants were nursed in incubators or cots. They were fed at first through polypropylene nasogastric feeding tubes of $0.96 \mathrm{~mm}$ outside diameter (30). When infants were able to suck, milk was given by bottle.

Milk. The infants were fed pooled pasteurized human breast milk. Sufficient milk for 10 days was placed in a stainless steel mixer, iron (ferrous sulfate) and vitamins $A, D$, and $C$ were 
added, and the whole well mixed. If the infant was tube fed, the milk for the 3 days of the balance was drawn up in disposable polystyrene syringes which were then capped with needles. When the infant was bottle fed the milk was measured into acidwashed sterile glass feeding bottles. The full syringes or bottles were weighed. A portion of the diet was taken for analysis, and the remainder was divided into seven storage jars to provide milk for the days between the balances. The milk was deep frozen until required.

The amount of milk given was determined by subtraction after weighing the used syringes or bottles and caps, together with any residual milk remaining in them. Spillages, regurgitations, and vomits were collected on ashless filter papers placed under the infant's head (Whatman 541 hardened ashless, $24.0 \mathrm{~cm}$ diameter). The soiled filter papers were preserved for analysis. A careful record of any accidents was kept by the nursing staff.

Stool Collection. On the day of the balance the child was bathed and all traces of ointments and powder were removed from the body. No powders or ointments were used during the balance. Carmine (50-100 mg), which contained insignificant amounts of trace metals, was given at the beginning and end of each balance to mark the stools. Stools were collected onto ashless filter papers (Whatman 541 hardened ashless, $11.0 \mathrm{~cm}$ diameter) held in place by polyethylene tie pants (28). The nurses handling the stools wore disposable polythene gloves and put the stools and filter papers into opaque Perspex paniers lined with polythene bags, which were hung on a trolley adjacent to the infant's incubator. Only distilled water and filter papers were used for cleaning the infant's bottom. Any leakage of stool was collected on $24.0-\mathrm{cm}$ diameter ashless filter papers placed under the infant.

Urine Collection. Urine bags measuring $\approx 3.0 \times 9.0 \mathrm{~cm}$ and pointed at the lower end were fashioned out of polyethylene sheet and fastened in place with silicone medical adhesive B (27). The urine was continuously aspirated into a chilled glass flask using the method of Liu and Anderson (9). Only the three girls were restrained on a mattress. Urine was collected throughout the balances and divided into three separate daily aliquots. This

Table 1. Details of infants

\begin{tabular}{llccrc}
\hline Infant & Sex & Birth wt, g & $\begin{array}{c}\text { Gestation, Weight, per- } \\
\text { weeks }\end{array}$ & $\begin{array}{c}\text { Duration of } \\
\text { sentile }\end{array}$ & $\begin{array}{l}\text { study, days } \\
\text { from birth }\end{array}$ \\
\hline$J C$ & M & 1123 & 27 & 60 th & $10-62$ \\
$S R$ & M & 1050 & 28 & 25 th & $10-72$ \\
$S F$ & M & 1400 & 31 & 30 th & $10-42$ \\
$H M$ & M & 1134 & 29 & 25 th & $10-72$ \\
$A R$ & M & 1165 & 30 & 20 th & $10-22$ \\
$D G$ & F & 1278 & 29 & 70 th & $10-42$ \\
& & & & & \\
$G B$ & F & 1258 & 37 & $<10$ th & $15-44$ \\
$T R$ & F & 1428 & 38 & $<10$ th & $10-34$ \\
\hline
\end{tabular}

1 Using data of Lubchenko et al. (10). enabled a correction to be made to the volume if a leakage occurred on one day. The three urine specimens were analyzed separately as a check on contamination.

Light for Dates Infants. The light for dates infants were studied at an earlier date than the preterm infants and the balance methods were slightly different. They are described in the report of Shaw (18). Although the methodology was less rigorous than in the later balances, preliminary experiments did not indicate any serious errors arising out of environmental contamination of specimens.

Analytic Methods. The filter papers containing regurgitated milk and the filter papers containing the stool were counted and the numbers recorded. Together with weighed aliquots of the diet, the stool and filter papers were placed in silica beakers, dried at $105^{\circ}$, and then ashed in a Muffle furnace at $450^{\circ}$ for 24$36 \mathrm{hr}$.

Magnesium, zinc, and copper were measured on acid extracts of the ash by atomic absorption spectrophotometry (29). A recovery experiment using the same method gave recoveries for copper $97 \%$, for zinc $100 \%$, and for magnesium $101 \%$. Blank values for the filter papers were also determined and subtracted from the results. Magnesium, zinc, and copper were measured directly in diluted or undiluted urine. The specimens from the light for dates infants were analyzed by one of us (M.J.D.) at the Medical Research Council Dunn Nutrition Unit, Cambridge (31).

\section{ACCUMULATION OF MAGNESIUM, ZINC, AND COPPER BY HUMAN} FETUS BETWEEN 24 AND 36 WEEKS OF GESTATION

Estimates of the rates of accumulation of magnesium, zinc, and copper by the human fetus are given in Table 2 . They are calculated from data on the composition of fetal bodies given in Widdowson and Dickerson (25), using the methods outlined by Shaw (17).

\section{RESUL'is}

\section{COMPOSITION OF MILK}

The results of analysis of the milk, and the volume ingested, are given in Table 3 . The light for date babies ingested $22 \%$ more milk than the preterm infants.

\section{PRETERM INFANTS}

Magnesium Absorption and Retention. The results of the magnesium balances are given in Table 4. Although magnesium intake per $\mathrm{kg}$ body weight remained fairly constant, absorption and retention increased with postnatal age, and so did the urinary magnesium. The mean absorption was $43 \%$ of intake (range 1 to $74 \%$ ) and the mean retention was $25 \%$ of intake (range -15 to $+48 \%$ ). The magnesium in the urine amounted to $43 \%$ of absorbed magnesium (range 36 to $49 \%$ ). Figure 1 gives contrasting examples of magnesium balances in single infants. The amount of magnesium absorbed by infant $J C$ was close to that being laid down by a fetus of equivalent gestation, but he

Table 2. Calculated rates of accumulation of magnesium, copper, and zinc by human fetus at different periods of gestation

\begin{tabular}{|c|c|c|c|c|c|c|}
\hline \multirow[b]{2}{*}{ Week of gestation } & \multicolumn{2}{|c|}{ Magnesium } & \multicolumn{2}{|c|}{ Zinc } & \multicolumn{2}{|c|}{ Copper } \\
\hline & $\mathrm{mg} /$ day & $\mathrm{mg} / \mathrm{kg} \cdot$ day & $\mathrm{mg} /$ day & $\mathrm{mg} / \mathrm{kg} \cdot$ day & $\mathrm{mg} /$ day & $\mathrm{mg} / \mathrm{kg} \cdot \mathrm{day}$ \\
\hline 24 & 1.9 & 3.8 & 0.169 & 0.337 & 0.039 & 0.078 \\
\hline 26 & 2.4 & 3.7 & 0.208 & 0.326 & 0.052 & 0.080 \\
\hline 28 & 3.1 & 3.8 & 0.256 & 0.315 & 0.067 & 0.083 \\
\hline 30 & 3.9 & 3.8 & 0.316 & 0.302 & 0.088 & 0.085 \\
\hline 32 & 5.0 & 3.8 & 0.389 & 0.293 & 0.116 & 0.087 \\
\hline 34 & 6.4 & 3.7 & 0.480 & 0.282 & 0.151 & 0.089 \\
\hline 36 & 8.1 & 3.7 & 0.591 & 0.272 & 0.199 & 0.092 \\
\hline
\end{tabular}


retained much less because of the large amount in the urine. $H M$, on the other hand, absorbed very little magnesium until after day 40 of life and excreted a correspondingly smaller amount in the urine. The poor magnesium absorption by $H M$ may have resulted from a period of diarrhea lasting from the 22 nd to the 32 nd day of life.

Zinc Absorption and Retention. The results of the zinc balances are given in Table 5. On a zinc intake that remained fairly constant, zinc absorption was negative on average until the 60 th day of life. On days 10-12 the negative zinc absorption was similar in all infants. Thereafter, it became more negative in some and less negative in others. Although there was great variability between infants, the pattern for any one infant was consistent. Since there were only small amounts of zinc in the urine, retention followed absorption closely. The amount of zinc in the urine each day remained constant until day 30 ; thereafter both the concentration of zinc in the urine and the amount of zinc excreted each day fell to very low levels. Figure 2 gives contrasting examples of zinc balances. Infant $S R$ was in negative balance on day 10 and moved steadily towards positive balance by day 45 . However, between day 10 and day 72 it is estimated that he had lost a total of $4.0 \mathrm{mg}$ zinc from his body. Infant $J C$ began with a similar negative zinc balance on days 10-12, which became more negative on days $20-22$. Thereafter, the negative balance steadily diminished but was never positive during the first 60 days of life. Between day 10 and day 72 of life it is estimated that this infant experienced a net loss of $37 \mathrm{mg}$ zinc from his body. The very large amounts of zinc in the feces led us to examine the possibility of contamination of the stools with zinc. The distribution of zinc was examined in the stool specimens from four consecutive 3-day balance periods. Of the zinc, $84 \%$ was in the stool easily removed from the filter papers, and a further $13 \%$ was smeared on the filter papers. Only $1 \%$ of the stool zinc was in the tie pant washings. The filter paper blank was $2 \%$ of the zinc in the stool specimen. This distribution of the mineral together with the low values in the urine makes significant environmental contamination with zinc very improbable.

Copper Absorption and Retention. The results of the copper balances are given in Table 6. Copper intake was quite constant but copper balance was at first negative, gradually becoming positive on average by day 35 . The amount of copper in the urine was small and diminished with postnatal age. Figure 3 gives contrasting examples of copper balances. The infant $S R$ was never observed to be in negative copper balance. Over the period of observation it is estimated he retained a total of $3.2 \mathrm{mg}$ copper; however, this was only $33 \%$ of the amount accumulated by a fetus over an equivalent period of gestation. Infant $H M$ began in negative balance and was not in positive balance until after day 40 . Between days 10 and 72 it is estimated he lost a total of $0.6 \mathrm{mg}$ copper from his body. No explanation is available for the change in copper and magnesium absorption in subject $H M$ on days $70-72$ (see figs. 1 and 3 ). Since it was not apparent in the zinc balances (and also calcium balances, not given here), errors in stool collection are an unlikely explanation. The change either represents a genuine fluctuation in the absorption of these elements, or results from contamination of the diet or stool specimens.

\section{LIGHT FOR DATE INFANTS}

The results of the magnesium, zinc, and copper balances on the light for date infants are summarized in Table 7. Compared with the data on the preterm infants there are certain differences.

Magnesium. Because of the larger intake of milk the light for dates infants had a magnesium intake of $7.2 \mathrm{mg} / \mathrm{kg} \cdot$ day, $16 \%$ more than the preterm infants. However, they absorbed on average 2-4 times as much magnesium as the preterm infants and retained 3 times as much.

Zinc. The zinc intake of these infants was $0.69 \mathrm{mg} / \mathrm{kg} \cdot$ day, similar to that of the preterm infants $(0.64 \mathrm{mg} / \mathrm{kg} \cdot$ day $)$. There were only two balance periods where balance was negative, and over the comparatively short period they were studied, one infant retained a total of $22 \mathrm{mg}$ and the other $18 \mathrm{mg}$ zinc.

Copper. The copper intake of the light for dates infants was on average $0.082 \mathrm{mg} / \mathrm{kg} \cdot$ day, a value comparable to that of the preterm infants $(0.083 \mathrm{mg} / \mathrm{kg} \cdot$ day $)$. There were, however, no periods of negative balance, and over the period of observation one infant retained $2.7 \mathrm{mg}$ and the other $1.8 \mathrm{mg}$ copper. Although the percentage of copper absorption was fairly constant in one infant $(T R)$, in the other $(G B)$ it increased steadily from $12 \%$ on days $15-19$ to $88 \%$ on days $40-44$.

\section{COMPARISON WITH FETUS IN UTERO}

Figure 4 gives the total postnatal accumulations of magnesium, zinc, and copper by the preterm infants over the period of

Table 3. Results of analyses of pooled pasteurized human breast milk for magnesium, zinc, and copper, and volume of milk ingested $( \pm S D)$

\begin{tabular}{lcc}
\hline & Preterm infants & $\begin{array}{c}\text { Light for dates term in- } \\
\text { fants }\end{array}$ \\
\hline $\begin{array}{l}\text { Magnesium, } \mathrm{mg} / 100 \\
\mathrm{ml}\end{array}$ & $2.99 \pm 0.38$ & $2.74 \pm 0.24$ \\
Zinc, $\mathrm{mg} / 100 \mathrm{ml}$ & $0.336 \pm 0.069$ & $0.275 \pm 0.14$ \\
Copper, $\mathrm{mg} / 100 \mathrm{ml}$ & $0.041 \pm 0.005$ & $0.31 \pm 0.012$ \\
& $216 \pm 11$ & $263 \pm 27$ \\
\hline
\end{tabular}

Table 4. Results of magnesium balances on preterm infants

\begin{tabular}{|c|c|c|c|c|c|c|c|c|c|}
\hline $\begin{array}{l}\text { Postnatal } \\
\text { age, days }\end{array}$ & $n$ & & Body wt, $g$ & $\begin{array}{c}\text { Intake, mg/ } \\
\mathrm{kg} \cdot \text { day }\end{array}$ & $\begin{array}{c}\text { Feces, mg/ } \\
\mathrm{kg} \cdot \text { day }\end{array}$ & $\begin{array}{l}\text { Absorption, } \\
\mathrm{mg} / \mathrm{kg} \cdot \text { day }\end{array}$ & $\begin{array}{c}\text { Urine, } \mathrm{mg} / 100 \\
\mathrm{ml}\end{array}$ & $\begin{array}{l}\text { Urine, } \mathrm{mg} / \\
\mathrm{kg} \cdot \text { day }\end{array}$ & $\begin{array}{l}\text { Retention, } \mathrm{mg} / \\
\mathrm{kg} \cdot \text { day }\end{array}$ \\
\hline \multirow[t]{2}{*}{$10-12$} & 6 & Mean & 1121 & 6.9 & 4.7 & 2.2 & 0.74 & 0.92 & 1.28 \\
\hline & & $\pm \mathrm{SD}$ & 136 & 0.8 & 1.3 & 1.3 & 0.87 & 1.05 & 1.56 \\
\hline \multirow[t]{2}{*}{$20-22$} & 6 & Mean & 1245 & 6.3 & 3.8 & 2.5 & 0.92 & 1.16 & 1.34 \\
\hline & & $\pm \mathrm{SD}$ & 177 & 0.4 & 1.1 & 1.3 & 0.97 & 1.26 & 1.03 \\
\hline \multirow[t]{2}{*}{$30-32$} & 5 & Mean & 1407 & 6.2 & 3.6 & 2.6 & 0.75 & 0.95 & 1.65 \\
\hline & & $\pm \mathrm{SD}$ & 283 & 1.2 & 0.8 & 1.3 & 0.71 & 0.89 & 1.0 \\
\hline \multirow[t]{2}{*}{$40-42$} & 5 & Mean & 1582 & 6.4 & 3.6 & 2.8 & 0.99 & 1.22 & 1.58 \\
\hline & & $\pm S D$ & 294 & 0.3 & 1.3 & 1.5 & 0.65 & 0.77 & 0.98 \\
\hline \multirow{2}{*}{$50-52$} & 3 & Mean & 1550 & 6.1 & 2.8 & 3.3 & 1.29 & 1.64 & 1.66 \\
\hline & & \pm SD & 90 & 1.4 & 0.2 & 1.6 & 1.04 & 1.26 & 0.49 \\
\hline \multirow[t]{2}{*}{$60-62$} & 3 & Mean & 1749 & 6.0 & 2.2 & 3.8 & 1.42 & 1.86 & 1.94 \\
\hline & & $\pm \mathrm{SD}$ & 77 & 1.4 & 0.6 & 1.3 & 1.04 & 1.36 & 0.19 \\
\hline \multirow[t]{2}{*}{$70-72$} & 2 & Mean & 1938 & 5.8 & 2.7 & 3.1 & 0.91 & 1.16 & 1.94 \\
\hline & & Range & $1904-1973$ & $5.2-6.3$ & $2.2-3.2$ & $2.1-4.1$ & $0.3-1.51$ & $0.41-1.9$ & $1.62-2.2$ \\
\hline
\end{tabular}


study as a percentage of the calculated intrauterine accumulation by a fetus of equivalent gestation, and compares them with the light for dates infants. The postnatal accumulation of the light for dates infants has been expressed as the percentage of the amount a fetus would have accumulated for an equivalent weight gain using the methods given in Shaw (18). They retained about as much copper as a fetus would for an equivalent weight gain, about twice as much magnesium, and about 2.5 times as much zinc.

\section{DISCUSSION}

In order to evaluate the data presented here, comparison has been made with the rate of accumulation of the different minerals by the human fetus in utero. Although the calculations of fetal accumulation rates may not be very precise and take no account of biologic variation, it is the hypothesis of this paper that they represent the best reference standard at present available for the nutrition of the preterm infant. Such comparisons serve to show how the chemical growth of the preterm infant differs from that of the fetus in utero, and may draw attention to unsuspected nutritional deficiencies.

\section{INTAKE}

Breast milk would only contain enough copper for the preterm low birth weight infants if they absorbed and retained $100 \%$ of their intake. If they retained $60 \%$ of the magnesium and $45 \%$ of the zinc in their diet (given at $200 \mathrm{ml} / \mathrm{kg}$ body $\mathrm{wt} \cdot$ day), they would retain amounts comparable to those laid down by a fetus

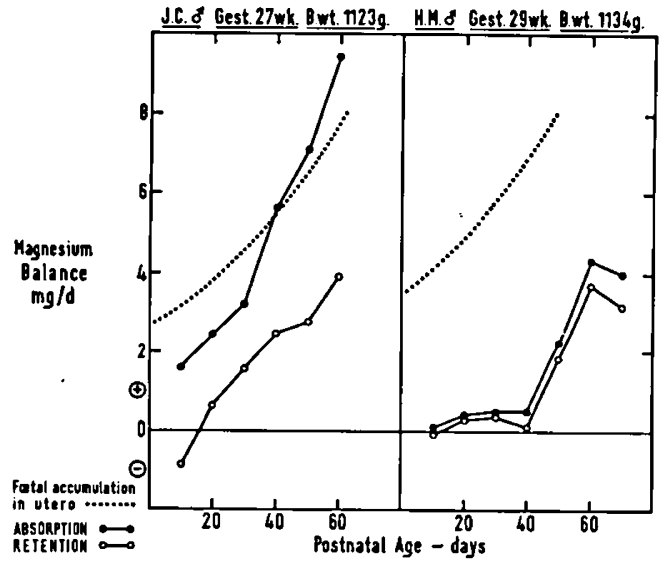

Fig: 1. Contrasting examples of magnesium balances in preterm infants. of equivalent gestational age in utero (see Tables 2 and 4), but they did not do so. The fact that the two term infants absorbed these substances so well suggests that the problem in the preterm infants is immaturity of the fetal intestine, rather than inadequate provision in the milk. However, as with iron (5), it may be possible to improve the absorption of these substances by augmenting the concentration in the diet.

\section{ABSORPTION AND RETENTION}

Magnesium. Some of the infants absorbed enough magnesium but passed so much in their urine that they did not retain enough (e.g., JC, Fig. 1). The magnesium in the urine may represent failure of renal conservation, or the excretion of a surplus not used for growth. The fact that the infant $H M$ (Fig. 1) was able to reduce this urinary magnesium to such low levels suggests that the losses of magnesium in the urine did not result from failure of renal conservation. If this is true, then (with the possible exception of infant $H M$ (Fig. 2)) the absorption of magnesium in these infants was not growth limiting. There is little known about the mechanism of magnesium absorption (20), and there is not much data on the amounts absorbed by very low birth weight preterm infants. Day et al. (6) reported values for magnesium retention by very low birth weight preterm infants fed SMA S.26 which ranged from about $3-5 \mathrm{mg} / \mathrm{kg} \cdot$ day. These values are $2-3$ times as great as those recorded here and most of their values were nearly twice those recorded by Widdowson (23) for term infants aged 4-6 weeks and fed SMA S.26. It is difficult to explain these very large differences. By the 60 th day of life the preterm infants

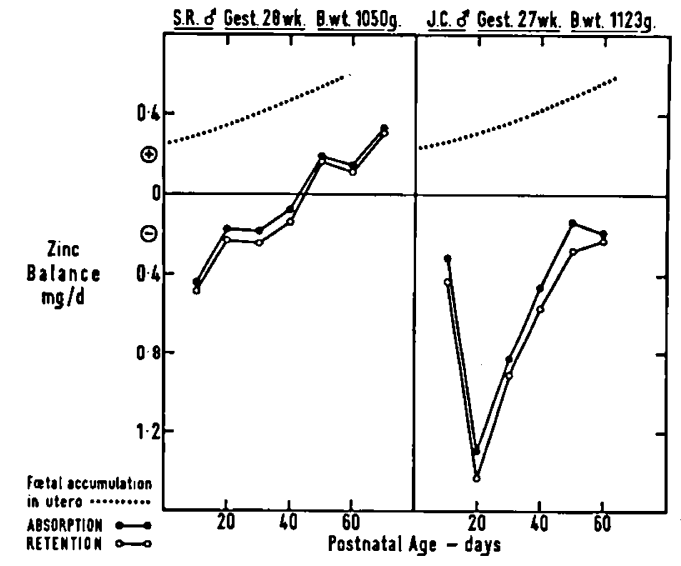

Fig. 2. Contrasting examples of zinc balances in preterm infants.

Table 5. Results of zinc balances on preterm infants

\begin{tabular}{|c|c|c|c|c|c|c|c|c|c|}
\hline $\begin{array}{l}\text { Postnatal } \\
\text { age, days }\end{array}$ & $n$ & & Body wt, g & $\begin{array}{c}\text { Intake, mg/ } \\
\mathrm{kg} \cdot \text { day }\end{array}$ & Feces, mg/kg · day & $\begin{array}{c}\text { Absorption, mg/ } \\
\mathrm{kg} \cdot \text { day }\end{array}$ & $\begin{array}{c}\text { Urine, } \mathrm{mg} / 100 \\
\mathrm{ml}\end{array}$ & $\begin{array}{c}\text { Urine, } \\
\mathrm{mg} / \\
\mathrm{kg} \cdot \mathrm{day}\end{array}$ & $\begin{array}{c}\text { Retention, mg/ } \\
\mathrm{kg} \cdot \text { day }\end{array}$ \\
\hline \multirow[t]{2}{*}{$10-12$} & 6 & Mean & 1121 & 0.621 & 1.058 & -0.437 & 0.048 & 0.062 & -0.499 \\
\hline & & $\pm S D$ & 136 & 0.186 & 0.252 & 0.175 & 0.026 & 0.028 & 0.178 \\
\hline \multirow[t]{2}{*}{$20-22$} & 6 & Mean & 1245 & 0.646 & 1.190 & -0.544 & 0.053 & 0.067 & -0.611 \\
\hline & & $\pm \mathrm{SD}$ & 177 & 0.149 & 0.46 & 0.389 & 0.030 & 0.038 & 0.423 \\
\hline \multirow[t]{2}{*}{$30-32$} & 5 & Mean & 1407 & 0.641 & 1.056 & -0.415 & 0.053 & 0.066 & -0.481 \\
\hline & & $\pm \mathrm{SD}$ & 283 & 0.177 & 0.366 & 0.438 & 0.033 & 0.046 & 0.481 \\
\hline \multirow[t]{2}{*}{$40-42$} & 5 & Mean & 1582 & 0.642 & 0.840 & -0.198 & 0.042 & 0.047 & -0.245 \\
\hline & & $\pm \mathrm{SD}$ & 294 & 0.156 & 0.303 & 0.172 & 0.027 & 0.025 & 0.194 \\
\hline \multirow[t]{2}{*}{$50-52$} & 3 & Mean & 1550 & 0.617 & 0.764 & -0.147 & 0.031 & 0.037 & -0.183 \\
\hline & & $\pm S D$ & 90 & 0.126 & 0.291 & 0.315 & 0.036 & 0.041 & 0.317 \\
\hline \multirow[t]{2}{*}{$60-62$} & 3 & Mean & 1749 & 0.599 & 0.598 & 0.001 & 0.014 & 0.018 & -0.017 \\
\hline & & $\pm \mathrm{SD}$ & 77 & 0.132 & 0.221 & 0.090 & 0.004 & 0.006 & 0.095 \\
\hline \multirow[t]{2}{*}{$70-72$} & 2 & Mean & 1938 & 0.710 & 0.559 & 0.151 & 0.009 & 0.011 & 0.140 \\
\hline & & Range & 1904-1973 & $0.651-0.770$ & $0.478-0.640$ & $0.127-0.173$ & $0.008-0.009$ & 0.011 & $0.116-0.163$ \\
\hline
\end{tabular}


$\mathrm{Mg}, \mathrm{Zn}$, AND $\mathrm{Cu}$ RETENTION WITH BREAST MILK

Table 6. Results of copper balances on preterm infants

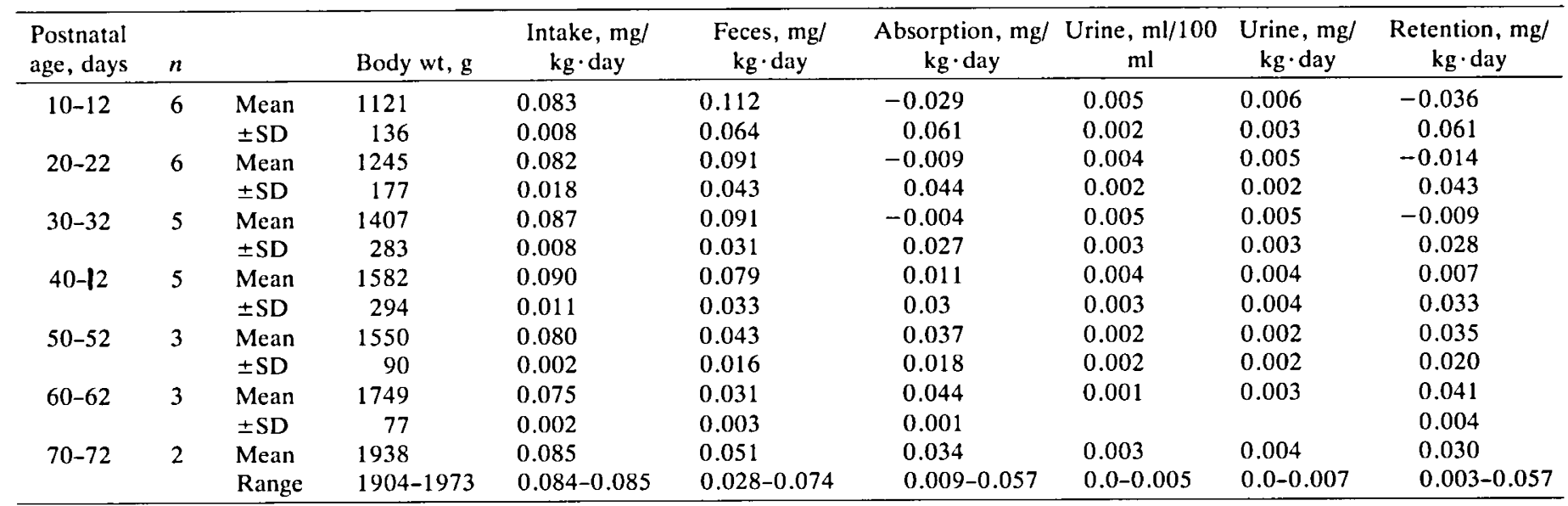

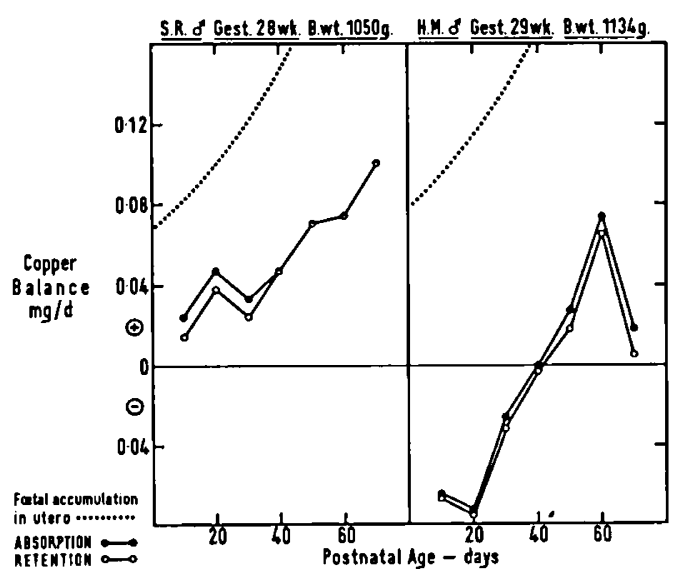

Fig. 3. Contrasting examples of copper balances in preterm infants.

in this study were retaining amounts of magnesium very close to the value of $1.9 \pm 1.0 \mathrm{mg} / \mathrm{kg} \cdot$ day for breast-fed full term infants aged 5-7 days reported by Widdowson (23) and the value of 1.6 $\pm 0.6 \mathrm{mg} / \mathrm{kg} \cdot$ day for breast-fed term infants aged $6-8$ days reported by Slater (19). In contrast the amount of magnesium retained by the two light for dates term infants was twice the value for term breast fed infants aged 4-6 weeks reported by Widdowson (23) $(2.7 \mathrm{mg} / \mathrm{kg} \cdot$ day (range $1.3-4.6]$. This suggests that these infants were experiencing catch-up growth and were repairing a body deficit (see Fig. 4).

Since the preterm infants retained on average $14.5 \mathrm{mg}$ magnesium/100 g weight gain, compared with $25 \mathrm{mg} / 100 \mathrm{~g}$ weight gain in the fetus, the reduced magnesium retention did not simply reflect slower growth. In the fetal body about $60 \%$ of the magnesium is in the bone (25), and much of the remainder is intracellular, where it is the second most abundant cation to potassium (22). It has been shown that less magnesium is laid down in the bone of preterm infants than in the bone of the fetus (12), but nothing comparable is known about magnesium in the soft tissues.

Zinc. Cavell and Widdowson (4) reported that term infants aged 6-8 days were in negative zinc balance, amounting on average to $-0.23 \mathrm{mg} / \mathrm{kg} \cdot$ day (range -0.85 to +0.08 ), and unpublished data of Fomon (7) suggests that zinc balance in term infants may on occasion be negative as late as the 4th month of life. The preliminary studies of Widdowson et al. (24) showed that negative zinc balance occurred in preterm infants after birth and persisted for at least 3 weeks in some cases. The results of the zinc balances reported here are surprising because it is difficult to understand how preterm infants can lose so much zinc from their bodies over such a long period without a serious effect on growth.

McCance and Widdowson (11) showed that zinc is lost from the body mainly through the intestine and they found that parenterally administered zinc appeared in the stool rather than the urine. Neither the magnitude of endogenous zinc secretion into the intestine nor the mechanism of reabsorption is known (3), but in the case of the infant $J C$, endogenous zinc excretion must have exceeded $1.0 \mathrm{mg} /$ day on days $20-22$. The failure of all the preterm infants to reabsorb even their endogenous zinc must have led to a depletion of body zinc in every case over the period of study. The reduction in the daily excretion of zinc in the urine with postnatal age certainly suggests depletion of body stores and Prasad et al. (14) have suggested that the apparent increase in zinc absorption seen in zinc deficiency may result from reduced endogenous zinc secretion into the intestinal lumen. The manifestations of zinc deficiency in childhood are anorexia, poor growth, and hypogeusia $(8,16)$, but the appearance of these symptoms may be delayed a year or more. The children with zinc deficiency described by Hambidge et al. (8) were all over 4 years of age, and some did not fall below their growth percentiles until the age of 2 years. From the data presented here it seems quite likely that some preterm infants will experience a period of zinc deficiency during the first year or so of life and they should be followed up with this in mind.

The light for dates term infants were different from the preterm infants. They absorbed large amounts of zinc (Table 7) and seemed to be attempting catch-up growth, insofar as they retained more zinc than a fetus would for an equivalent weight gain (Fig. 4). They would seem less likely than the preterm infants to run into zinc deficiency later on but this might depend on how much zinc they had in their bodies at birth.

Copper. Seven of the 10 term breast-fed infants aged 6-8 days reported by Cavell and Widdowson (4) were in negative copper balance (mean -0.009 , range +0.029 to $-0.066 \mathrm{mg} / \mathrm{kg} \cdot$ day) There is no data on how long the negative copper balance might persist in term infants but the data of Widdowson et al. (24) showed that negative copper balance occurred in preterm infants after birth, and might persist for 3 weeks or more. The results given here show that the copper balances became positive on average on the 35 th day of life. Only three of the six infants experienced a net loss of copper from their bodies over the period of the study and compared with zinc the amounts were relatively small. Nevertheless, all the infants absorbed quite inadequate amounts of copper and as they approached full term their liver copper stores must have been very low indeed. AlRashid and Spangler (1) and Ashkenazi et al. (2) have described severe copper deficiency occurring in two preterm infants of 34 and 30 weeks of gestation, who presented at 3 and 6 months, respectively. The cardinal signs are failure to thrive, anaemia, 
DAUNCEY, SHAW, AND URMAN

Table 7. Results of balances on two light for dates infants

\begin{tabular}{|c|c|c|c|c|c|c|}
\hline & \multicolumn{2}{|c|}{ Magnesium } & \multicolumn{2}{|c|}{ Zinc } & \multicolumn{2}{|c|}{ Copper } \\
\hline & Mean & Range & Mean & Range & Mean & Range \\
\hline $\begin{array}{l}\text { Absorption } \\
\mathrm{mg} / \mathrm{kg} \cdot \text { day } \\
\%\end{array}$ & $\begin{array}{l}5.7 \\
81\end{array}$ & $\begin{array}{c}4.0-7.2 \\
51-95\end{array}$ & $\begin{array}{c}0.44 \\
56\end{array}$ & $\begin{array}{c}-0.06-+0.75 \\
-35-+86\end{array}$ & $\begin{array}{l}0.045 \\
57\end{array}$ & $\begin{array}{c}0.004-0.079 \\
12-88\end{array}$ \\
\hline $\begin{array}{l}\text { Retention } \\
\mathrm{mg} / \mathrm{kg} \cdot \text { day } \\
\%\end{array}$ & $\begin{array}{c}5.4 \\
76\end{array}$ & $\begin{array}{c}3.3-6.6 \\
41-88\end{array}$ & $\begin{array}{l}0.42 \\
52\end{array}$ & $\begin{array}{c}-0.08-+0.73 \\
-46-+82\end{array}$ & $\begin{array}{l}0.045 \\
57\end{array}$ & $\begin{array}{c}0.004-0.079 \\
12-88\end{array}$ \\
\hline
\end{tabular}

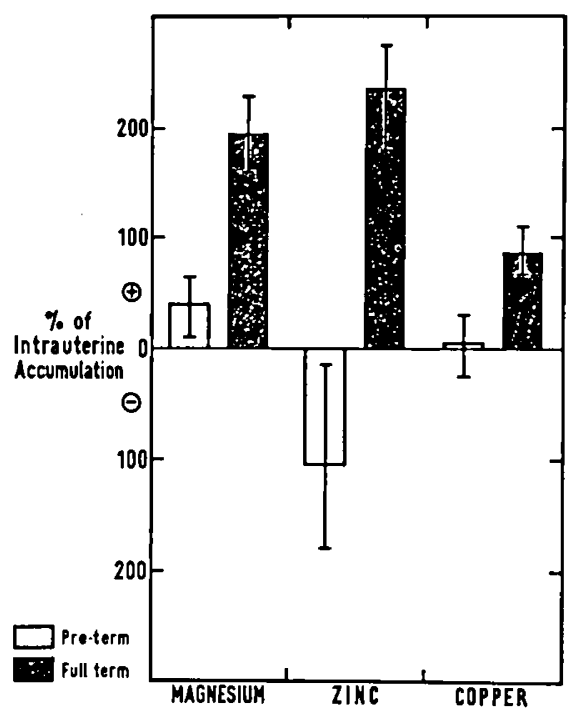

Fig. 4. Comparison of the accumulation of $\mathrm{Mg}, \mathrm{Cu}$, and $\mathrm{Zn}$ by preterm and full term light for dates infants. The values for the preterm infants are expressed as a percentage of intrauterine accumulation by a fetus over an equivalent period. The values for the full term infants are expressed as a percentage of the amount laid down in a fetus for an equivalent weight gain.

neutropenia, and bone disease, together with a low concentration of copper and ceruloplasmin in the plasma. The apparent failure of Wilson and Lahey (26) to induce copper deficiency in low birth weight infants given milk supplying $0.014 \mathrm{mg} / \mathrm{kg} \cdot$ day for 7-10 weeks indicates that severe copper deficiency is not inevitable in the first 6 months of life, although it may develop later on. However, the absence of significant difference between the infants on a high and low copper diet in their study may have resulted from the fact that both groups were equally copper deficient through malabsorption. Marginal copper deficiency is probably much more common than the severe cases quoted above and is probably much more difficult to detect.

\section{CONCLUSION}

1. Breast milk probably contains sufficient magnesium for preterm infants. Most cases absorbed enough, but retained too little because they passed so much in the urine.

2 . The concentrations of copper and zinc in breast milk were too low to enable preterm infants to remain in copper balance until the 35 th day of life, and in zinc balance until the 60 th day of life.

3. The two light for dates term infants had no difficulty in absorbing the magnesium, copper, and zinc present in breast milk.

4. These data suggest that the problems experienced by the preterm infants may result from immaturity of the fetal alimentary tract.

5. The depletion of body stores of copper and zinc means that preterm infants are likely to develop deficiencies of these substances later in infancy.

6. Consideration should be given to supplementing the diets of preterm infants with copper and zinc.

\section{REFERENCES AND NOTES}

1. Al-Rashid, R. A., and Spangler, J.: Neonatal copper deficiency. N. Engl. J. Med., 285: 841 (1971).

2. Ashkenazi, A., Levin, S., Djaldetti, M., Fishel, E., and Benvenisti, D.: The syndrome of neonatal copper deficiency. Pediatrics, 52: 525 (1973).

3. Becker, W. M., and Hoekstra, W. G.: Intestinal absorption of zinc. In: S. C. Skoryna and D. Waldron-Edward: Intestinal Absorption of Metal Ions Trace Elements and Radionuclides (Pergamon Press, Oxford, 1971).

4. Cavell, P. A., and Widdowson, E. M.: Intakes and excretions of iron, copper and zinc in the neonatal period. Arch. Dis. Childhood, 39: 496 (1964).

5. Dauncey, J., Shaw, J. C. L., and Urman, J.: Iron absorption by low birth weight infants from pasteurized human breast milk [Abstr.]. (In press.)

6. Day, G. M., Chance, G. W., Radde, I. C., Reilly, B. J., Park, E., and Sheepers, J.: Growth and mineral metabolism in very low birth weight infants. II. Effects of calcium supplementation on growth and divalent cations. Pediat. Res., 9: 568 (1975).

7. Fomon, S. J.: Infant Nutrition, Ed. 2 (W. B. Saunders, Philadelphia, 1974).

8. Hambidge, K. M., Hambidge, C., Jacobs, M., and Baum, J. D.: Low levels of zinc in hair, anorexia, poor growth and hypogeusia in children. Pediat. Res., 6: 868 (1972).

9. Liu, H. Y., and Anderson, G. J.: A method for long term quantitative and fractional urine collection. J. Pediat., 70: 276 (1967)

10. Lubchenko, L. O., Hansman, C., Dressler, M., and Boyd, E.: Intrauterine growth as estimated from live born birth weight data at 24 to 42 weeks of gestation. Pediatrics, 32: 793 (1963).

11. McCance, R. A., and Widdowson, E. M.: The absorption and excretion of zinc. Biochem. J., 36: 692 (1942).

12. McIntosh, N., Shaw, J. C. L., and Taghizadeh, A.: Direct evidence for calcium and trace mineral deficits in the skeleton of preterm infants. Pediat. Res., 8: 896 (1974).

13. Porter, M.: In: J. Peisach, P. Aisen, and W. E. Blumberg: The Biochemistry of Copper, p. 159 (Academic Press, New York, 1966).

14. Prasad, A. S., Miale, A., Farrid, Z., Sandstead, H. H., and Schulert, A. R.: Zinc metabolism in patients with the syndrome of iron deficiency anaemia, hepatospleno megaly, dwarfism, and hypogonadism. J. Lab. Clin. Med., 61: 537 (1963).

15. Royer, P.: Growth and development of bony tissue. In: J. A. Davis and J. Dobbing: Scientific Foundations of Paediatrics. (William Heinemann Medical Books Ltd., London, 1974).

16. Schechter, P. J., Friedewald, W. T., Bronzert, D. A., Raff, M. S., and Menkin, R. I.: Idiopathic hypogeusia: A description of the syndrome and a single blind study with zinc sulphate. Int. Rev. Neurobiol. Suppl., 1: 125 (1972).

17. Shaw, J. C. L.: Parenteral nutrition in the management of sick low birth weight infants. Pediat. Clin. North Amer., 20: 333 (1973).

18. Shaw, J. C. L.: Evidence for defective skeletal mineralization in low birth weight infants. Pediatrics, 57: 16 (1976).

19. Slater, J. E.: Retentions of nitrogen and minerals by babies 1 week old. Brit. J. Nutr., 15: 83 (1961).

20. Tansy, M. F.: Intestinal absorption of magnesium. In: S. C. Skoryna and D. Waldron-Edward: Intestinal Absorption of Metal Ions, Trace Elements and Radionuclides. (Pergamon Press, Oxford, 1971).

21. Tkacenko, S. K.: Postuplenie i vyredenie nekotoryh microe̊lementov̌ u nedonosennyh detj. (Intake and excretion of some trace elements in premature infants.) Pediatrija, 10: 10 (1970).

22. Wacker, W. E. C., and Parisi, A. F.: Magnesium metabolism. New Engl. J. Med., 278: 658, 712, 772 (1968).

23. Widdowson, E. M.: Absorption and excretion of fat, nitrogen and minerals 
from "filled" milks by babies one week old. Lancet, $i i$ : 1099 (1965).

24. Widdowson, E. M., Dauncey, J., and Shaw, J. C. L.: Trace elements in fetal and early postnatal development. Proc. Nutr. Soc., 33: 275 (1974).

25. Widdowson, E. M., and Dickerson, J. W. T.: In: C. L. Comar and F. Bronner: Mineral Metabolism. Vol. II, Part A (Academic Press, New York 1961).

26. Wilson, J. F., and Lahey, M. E.: Failure to induce dietary deficiency of copper in premature infants. Pediatrics, 25: 40 (1960).

27. Dow Corning Corporation, Medical Products, Midland, Mich.

28. Lewis Woolf Griptight Ltd., Selly Oak, Birmingham, England.

29. Perkin Elmer, atomic absorption spectrophotometer, model 306.

30. Portex Ltd., Hythe, Kent, England.

31. Pye Unicam, atomic absorption spectrophotometer, model S.P.90.

32. We are grateful to all the nurses who took such care with the balances and to

Copyright (C) 1977 International Pediatric Research Foundation, Inc.
Calvin Davies for his accurate work in the laboratory.

33. The work presented here was supported by a grant from the Medical Research Council, England.

34. The present address of Dr. M. J. Dauncey is: Medical Research Council Dunn Calorimetry Group, Institute of Animal Physiology, Babraham, Cambs.

35. Dr. J. Urman is a British Council scholar. Present address: Department of Paediatrics, Htal. Mat. Inf. R. Sarda, Luca 2151, Buenos Aires, Argentina.

36. Requests for reprints should be addressed to: J. C. L. Shaw, M.D., Department of Paediatrics, University College Hospital, Gower St., London, W.C.1. (England)

37. Received for publication October 22, 1976.

38. Accepted for publication February 15, 1977.
Carbonic anhydrase red blood cell renal tubular acidosis

\title{
Red Blood Cell Carbonic Anhydrase Activity in Children with Distal Renal Tubular Acidosis
}

\author{
B. S. KAPLAN, ${ }^{(17)}$ M. MILLS, P. HECHTMAN, AND D. LEBLANC
}

Departments of Nephrology and Biochemical Genetics, McGill University-Montreal Children's Hospital Research Institute, and Medical Research Council of Canada Human Genetics Group, Montreal, Quebec, Canada

\section{Summary}

Red blood cell carbonic anhydrase activity was studied in three children with distal renal tubular acidosis, the parents of one of these patients, and in control subjects. Although each patient had distal renal tubular acidosis as defined by an inappropriately high urine $\mathrm{pH}$ in the face of a systemic metabolic acidosis, hyperchloremia and a low (U-B)pCO $\mathrm{O}_{2}$, they differed in that two had deafness. The deafness was inherited as an autosomal recessive mode in one and by an autosomal dominant gene in the other.

Red blood cell carbonic anhydrase activity was determined in hemoglobin-free hemolysate by the esterolytic action of the enzyme on the substrate $p$-nitrophenyl acetate. The two isoenzymes, $B$ and $C$, of carbonic anhydrase were identified using polyacrylamide disc gel electrophoresis. The red blood cell carbonic anhydrase activity of nine control children aged 2-10 years was $3.8(3.2-5.0)$ units/g $\mathrm{Hb}$. The values obtained from the three patients were $3.0,3.7$, and 4.36 units $/ g$ Hb. These did not differ from those of the control subjects. No abnormalities were found in the ratios of the $B$ and $C$ peaks or in their electrophoretic mobility.

\section{Speculation}

Although carbonic anhydrase appears to have an important role in the acidification of the urine, and although an abnormality in red blood cell carbonic anhydrase has been described in a patient with renal tubular acidosis and deafness, no abnormalities could be defined in red blood cell carbonic anhydrase activity in our three patients with renal tubular acidosis, two of whom were deaf.

Patients with renal tubular acidosis (RTA) have reduced hydrogen ion secretion or bicarbonate reclamation which results in hyperchloremic metabolic acidosis and an inappropriately alkaline urine $\mathrm{pH}$. Although the pathogenesis of RTA is incompletely understood, two main forms of RTA have been defined (10): distal RTA (type I), in which there is reduced secretion of hydrogen ions into the urine, and proximal RTA (type II), in which there is incomplete reclamation of filtered bicarbonate by the proximal tubule.

Carbonic anhydrase (CA) is an enzyme which has a role in the regulation of the acid-base status of the body. There appear to be two major isoenzymes of CA (12): C (high activity) and B (low activity). CA can be demonstrated in two main sites in the nephron: in the proximal and distal tubular cells themselves and in the brush border of the proximal tubular cells (11). Shapira et al. (14) found abnormal red blood cell CA activity in three members of a kindred with RTA and deafness. This abnormality was described as an inactive mutant form of CA B. Since there does not appear to be tissue specificity for CA (6), these workers postulated a similar defect in the renal tubular cells of their patients. Although this could be an important observation about the pathogenesis of RTA, these findings have not been verified.

We have studied red blood cell CA activity in three children with RTA, two of whom were deaf, but were unable to demonstrate any abnormality in the red blood cell CA isoenzymes.

\section{MATERIALS AND METHODS}

\section{CA ACTIVITY OF HEMOGLOBIN-FREE HEMOLYSATE (HFH)}

HFH was prepared from heparinized fresh blood after determination of the hematocrit (14). Red blood cell CA activity is present in both the raw hemolysate and in the HFH. The latter is used as the CA activity is not stable in the raw hemolysate. Unfortunately, it was not possible to remove all the hemoglobin from the $\mathrm{HFH}$ and this accounted for the presence of small amounts of residual hemoglobin. CA activity of reconstituted 